\title{
Relación entre teatro e iconografía: el tema de Orestes y las Erinias
}

\author{
Relationship between theater and iconography: \\ the topic de Orestes and the Erinias
}

\author{
Mercedes Aguirre*
}

\begin{abstract}
RESUMEN
Este artículo examina cómo la iconografía de las Erinias castigando al matricida

Orestes puede estar inspirada por la representación de la tragedia Euménides y cómo la concepción de las Erinias para la obra teatral puede haber surgido de modelos iconográficos preexistentes.

Asimismo esta relación entre las representaciones de la Orestía de Esquilo y las representaciones artísticas del tema se puede ver en el arte posterior, con ejemplos en la pintura a partir del siglo XVIII.
\end{abstract}

PALABRAS CLAVE:

Erinias, Furias, teatro, iconografía, Euménides.

\begin{abstract}
This article examines how the iconography of the Erinyes punishing the matricide Orestes could have been inspired by performances of Aeschylus' Eumenides and how the way to conceive the Erinyes could have developed from some preceding iconographical models. Likewise a relation between teatre performances of Aeschylus" Oresteia and artistic representations of Orestes pursued by the Furies can also be seen in later art, with examples from 18th century onwards.
\end{abstract}

KEYWORDS:

Erinyes, Furies, teatre, iconography, Eumenides.

En la mitología griega las Erinias son las divinidades de la venganza, del castigo, especialmente del castigo de los parricidas, es decir, aquellos que han cometido un crimen dentro de su familia; en esos casos eran las encargadas de restablecer el orden que había sido alterado. Por su carácter negativo parece que no tenían culto en Grecia lo mismo que otros dioses, a pesar de que en Esquilo se hable de sacrificios a ellas. Luego veremos cómo en este mismo autor sufrirán una transformación para ser veneradas en Atenas — bajo el nombre de Euménidesen un lugar próximo a la Acrópolis.

* Departamento de Filología Griega y Lingüística Indoeuropea. Facultad de Filología. Universidad Complutense. 28040 Madrid. E-mail: macics@yahoo.co.uk 
A pesar de que el nombre de Erinia está ya citado en las tablillas micénicas, el testimonio más antiguo que nos da su origen es el de Hesíodo en la Teogonía1. Así, según él nacieron de las gotas de sangre procedentes de la castración de Urano, que al caer a la tierra fecundaron a Gea. De la misma forma nacerán también los Gigantes y las Ninfas Melias:

«...pues cuantas gotas de sangre desprendieron, todas las recogió Gea y, transcurrido el tiempo, dio a luz a las poderosas Erinias, a los grandes Gigantes, resplandecientes con el brillo de sus armas, con largas lanzas en sus manos, y a las Ninfas que llaman Melias en la inmensa tierra.»

Homero las cita en varias ocasiones pero no da ningún dato sobre su nacimiento o su aspecto, aparte de considerarlas odiosas y terribles, diosas vengadoras que viven en la oscuridad y restablecen el orden natural de las cosas, aunque también las considera las diosas que protejen los juramentos y castigan a los que los rompen².

Sin embargo, es más importante el testimonio de Esquilo en la Orestía, concretamente en la tragedia Euménides, en donde aparecen como las vengadoras de la muerte de Clitemestra, acosando al matricida Orestes. Y este es el tema más significativo en relación con ellas y en el que me voy a centrar. Aquí muestran realmente su carácter de divinidades terribles y espantosas que deben ser aplacadas. Ellas forman el coro de la tragedia y su papel es, en efecto, perseguir a Orestes exigiendo venganza ${ }^{3}$. En una ocasión van a ser incluso incitadas por el fantasma de la propia Clitemestra, que se les aparece en sueños para que no descansen en su tarea de perseguir al asesino Orestes recordándoles cuál es su cometido 4 .

En Esquilo las Erinias son hijas de Noche, por tanto tienen una genealogía diferente a la de Hesíodo:

Coro de Erinias: «Oh Noche, madre mía, madre que me engendraste para que fuera castigo de los que ya no ven la luz y de los que la ven, escúchame... ${ }^{5}$

Son negras - de ropajes negros-y espantosas. Su descripción aparece ya en Coéforos:

"Oh, oh, hay, esclavas, ahí unas mujeres como Gorgonas. ¡Van vestidas de negro y enmarañadas en múltiples serpientes! ${ }^{6}$

Y también en distintos pasajes de Euménides:

Teog. 183-185.

${ }^{2}$ Como diosas vengadoras aparecen por ejemplo en II. 9.571, 21.412. Como las que castigan a los que violan los juramentos en II. 19.259 y, en general sobre su naturaleza y función, en Od. 2.135.

3 Para A. L. Brown («The Erinyes in the Oresteia: Real life, the supernatural and the stage», Journal of Hellenic Studies 103 (1983) 21-22) aunque las Erinias en Coéforos sean probablemente un producto del estado mental de Orestes simbolizando su locura tras haber matado a su madre, en Euménides se transforman en una realidad física. Cf. también P. Easterling, "Theatrical Furies: Thoughts on Eumenides Performance, iconography, reception», en H. Revermann-P. Wilson (ed.), Studies in Honour of Oliver Taplin, 219-236.

${ }^{4}$ Euménides, 94-139.

5 Euménides, 321-323.

6 Coéforos, 1048-50. 
Pitia: «Delante de este hombre duerme un extraño grupo de mujeres que ocupan los asientos. No quiero decir mujeres, sino Gorgonas, pero ni a Gorgonas puedo compararlas por su aspecto, ni siquiera con las Harpías, que, dotadas de alas, ya vi una vez pintadas, arrebatándole la comida a Fineo. Pero éstas se ve que carecen de alas, son de color negro y en todo repugnantes: roncan con resoplidos repelentes y de sus ojos segregan humores odiosos... "»

Su carácter nocturno y oscuro se destaca en la misma obra en numerosas ocasiones, en contraste con Apolo, dios de la luz. Son consideradas diosas del mundo subterráneo, divinidades infernales, relacionadas con los muertos, a las que hay que hacer los sacrificios debidos: «Mucho habéis lamido ya de mis manos: libaciones sin vino -ofrendas apaciguadoras que no embriagaban- y festines ofrecidos de noche sobre el altar del fuego, a una hora no compartida con ningún dios... »8. Finalmente serán aplacadas por Atenea tras el juicio a Orestes y denominadas Las Euménides, es decir Las Bienhechoras —de ahí precisamente el nombre de la tragedia.

La iconografía de las Erinias en el arte griego ha recibido siempre la influencia del teatro en la medida en que proponía imágenes de ellas en escena y asimismo su papel fundamental y protagonista en Euménides ha tenido que influir en la popularidad de sus imágenes. Por ello de las representaciones que tenemos las más abundantes y más fáciles de identificar son las de la escena con Orestes ${ }^{9}$. En otros casos, cuando aparecen aisladas o en el Hades, su identificación es más difícil si no llevan sus nombres inscritos: Tisífona, Meguera y Alecto $^{10}$. En cualquier caso son siempre representadas bajo forma humana, femenina, tanto solas como en grupo, con algunos atributos que van a ser característicos y que van a ir configurando su iconografía.

Hay quienes piensan que en algunas imágenes sobre cerámica en las que aparece un guerrero o un personaje masculino luchando con una serpiente o huyendo de ella se puede identificar a Orestes y una Erinia en forma de serpiente, deduciendo de ahí una primitiva forma de serpiente para las Erinias, pero esto no es completamente seguro ${ }^{11}$. En cualquier caso las únicas representaciones seguras que tenemos de ellas las presentan ya con forma antropomórfica.

7 Euménides, 46-54.

8 Así dice el fantasma de Clitemestra cuando recrimina a las Erinias por estar dormidas en lugar de perseguir a Orestes (Euménides, 106-109).

9 Una visión general de la iconografía de las Erinias por ejemplo en: H. Sarian, «Erinys» LIMC III,1, 825-843; M. Junge, Untersuchungen zur Ikonographie der Erinys in der Griechischen Kunst (1983); $\mathrm{H}$ Sarian, «Refléxions sur l'iconographie des Erinyes dans le milieu grecque, italiote, et etrusque» en Iconographie classique et identités regionales. BCH 14 (1986), 25-35; F. Lissarrague, «Comment peindre les Érinyes?, Metis 4 (2006), 30-70.

10 Estos nombres no aparecen documentados ni en Hesíodo ni en Esquilo. Es en Apolodoro (Bibl. 1.1.4) y en Virgilio (Eneida 6.570-72) donde los encontramos por primera vez en una fuente literaria. Sin embargo sí aparecen inscritos sobre algunos de los vasos de cerámica griegos, ya en el siglo IV a.C., lo que muestra su antigüedad.

11 Sería una primitiva versión del tema de Orestes y las Erinias previa a la tragedia de Esquilo, quizá inspirada en Estesícoro, cf. A.J.N.W. Prag, The Oresteia. Iconographic and Narrative Tradition, Londres (1985) y A. Sommerstein, Aeschylus Eumenides, Cambridge (1989), 1, 9. 
Parece posible que fuera el propio Esquilo el que introdujera esa imagen antropomórfica de las Erinias, formada sobre imágenes conocidas de otras figuras femeninas como las Harpías o las Gorgonas cuando éstas ya han perdido su carácter monstruoso en el arte griego ${ }^{12}$. Así el propio texto de Esquilo hace una referencia a la semejanza de las Erinias con las Gorgonas y las Harpías tanto al final de Coéforos como al principio de Euménides en los pasajes arriba citados ${ }^{13}$.

A partir de entonces es posible que los artistas de mediados del siglo $v$ a.C. se inspiraran en esta concepción de las Erinias y la adoptaran. Parece haber una constante influencia de la obra artística en la dramática y viceversa. Siendo ambas cosas imágenes visuales que de alguna manera tenían que ser reconocibles, no podían estar demasiado alejadas la una de la otra.

Las primeras imágenes de las Erinias en el mito de Orestes aparecen en la cerámica ática. $Y$ en ellas está clara la influencia de las representaciones teatrales de Euménides pues no hay muchos vasos de fecha anterior a la primera representación de la Orestía que tuvo lugar en Atenas en el año 458 a.C. En los vasos suritálicos, aunque se mantiene el esquema y las escenas están sin duda inspiradas por la obra de Esquilo, los artistas introducen novedades que no se corresponden siempre con la iconografía fijada en los documentos áticos, como veremos a continuación. Como ya he dicho, son representadas como figuras femeninas, sus rostros siempre aparecen como los rostros de unas mujeres normales y en ningún caso parecen sugerir unas máscaras de aspecto terrorífico como se supone que eran las que llevaban los coreutas de la representación de Euménides. Pueden aparecer con atuendo de cazadoras, con quitón corto y botines, aunque su aspecto y sus atributos se combinan, incluso en la misma escena. En ocasiones son representadas con grandes alas desplegadas ${ }^{14}$. Lo que sí es constante son las serpientes que llevan en las manos, se mezclan con sus cabellos o se enroscan en sus brazos. Una espada, una lanza o una o más antorchas también figuran como atributos. La antorcha aparece asimismo en las escenas en el mundo infernal donde está clara la relación de este atributo con la oscuridad, con el hecho de que el Hades es un lugar oscuro y sombrío; sin embargo, la antorcha parece ser un atributo suyo original que es representado ya en las escenas de Euménides -algunas de fecha anterior - y no tiene necesariamente que haberse originado en la iconografía de éstas en el Hades ${ }^{15}$. Por otro lado no hay imágenes en las que Orestes se defienda de ellas con un arco dado por Apolo (como refiere Estesícoro), pero sí

12 Algunas ideas sobre cómo Esquilo desarrolla su concepción de las Erinias para Euménides en Prag, o.c., 48-49.

13 Cf. notas 4 y 5 .

${ }^{14} \mathrm{El}$ hecho de que en el texto de Esquilo se diga expresamente que las Erinias no tienen alas, mientras que en algunas de las representaciones artísticas pueden aparecer aladas, podría deberse a que sería difícil poner en escena un coro de mujeres con alas o bien a esa constante interrelación con las Gorgonas a la que he aludido. Eurípides alude a las alas de las Erinias en Orestes v. 316 aunque en esta tragedia las Erinias no aparecen físicamente en escena. Sobre las alas de las Erinias y también la aparición de éstas en escena cf. O. Taplin, The stagecraft of Aeschylus, Oxford (1977) 369 ss.

${ }_{15}$ Es posible que haya una relación estrecha de las Erinias con la noche y la oscuridad (y no sólo por el parentesco con Noche al que alude Esquilo), pudiendo incluso pensarse que éstas actuaban únicamente de noche, durmiendo durante el día (como los vampiros). Homero las llama «las que caminan en la oscuridad» (llíada 19.87). 
suele aparecer blandiendo una espada, tal como se le describe en el prólogo de Euménides. La espada, además de ser el arma con que se defiende, recuerda el crimen que ha cometido.

El número de Erinias en estas escenas es de dos o tres, es decir, el número que se les atribuye en el mito - a las que incluso se les da tradicionalmente los nombres de Tisífone, Meguera y Alecto, como ya he dicho-, y no los doce coreutas que tendría el coro de Euménides ${ }^{16}$. Hay que tener en cuenta que los artistas parten de la escena mitológica y no de la teatral y no suelen representarlas como un coro.

Podemos ver ahora algunos ejemplos de los distintos momentos del episodio representados sobre cerámica griega, comenzando por las imágenes de las Erinias con Orestes en Delfos:

Una hidria ática de figuras rojas (hacia el 450 a.C.) muestra a diversos personajes: Orestes, Apolo, Ártemis y -a la derecha viniendo en la dirección de Orestes- dos Erinias con serpientes en los cabellos y en cada mano, una vestida con túnica corta y la otra con túnica larga.

Un pélice ático de figuras rojas (380-360 a.C.) es el primer vaso ático que muestra a Orestes sobre el ónfalos, en la postura que luego se repetirá en otras imágenes ${ }^{17}$. Dos Erinias sin alas —una a cada lado- amenazan a Orestes con sus antorchas. Van vestidas con túnicas largas y tienen serpientes en los cabellos.

Una cratera de cáliz apulia de figuras rojas (360-350 a.C. aproximadamente) ofrece una escena que podría recrear una representación de la escena de Euménides, con un edificio de columnas que sugiere un escenario teatral ${ }^{18}$ y la Pitia huyendo horrorizada ante el espectáculo de las Erinias, como se supone que ocurre en el prólogo de la tragedia. Abajo cinco Erinias están dormidas en el suelo ${ }^{19}$. Es la única ocasión en que las Erinias están representadas con las caras y el cuerpo negros y las túnicas blancas.

Una cratera de volutas apulia (360-350 a.C.) muestra una escena con una composición diferente: Apolo aparece montado sobre un cisne, Orestes con la espada en la mano es atacado por dos Erinias aladas que vienen de la derecha, una lleva una lanza, otra una antorcha encendida. Una tiene el quitón corto, otra largo $\mathrm{y}$ tienen serpientes en los cabellos y en los brazos.

16 Cf. A.H. Sommerstein, Aeschylus Eumenides, Cambridge (1989) 34.

17 Cf. A.D. Trendall-T.B.L. Webster, Illustrations of Greek Drama, Londres (1972) 45.

18 Sobre las imágenes de la cerámica griega relacionadas con una representación dramática cf. por ejemplo L. Séchan, Etudes sur la tragedie grecque dans ses rapports avec la céramique, París (1967); A.D. Trendall-T.B.L. Webster, Illustrations of Greek Drama, Londres (1972); O. Taplin, Comic Angels and other approaches to Greek Drama through Vase Painting, Oxford (1993); M. Aguirre, «Imágenes del teatro griego y su puesta en escena» Acotaciones. Revista de investigación teatral (2006), 20-27.

19 Dada la discusión acerca de si las Erinias estaban o no presentes durante el prólogo de la Pitia (cf. O. Taplin, The stagecraft of Aeschylus 369-374), esta escena podría ser interpretada de dos maneras: o bien como un testimonio de que sí estaban o como una interpretación del pintor del vaso que no refleja lo que se veía en escena. Sobre esta imagen cf. también Trendall-Webster, o.c., 46 y D. Knoepfler Les imagiers de l'Orestie, Neuchatel (1993), 75-76. 


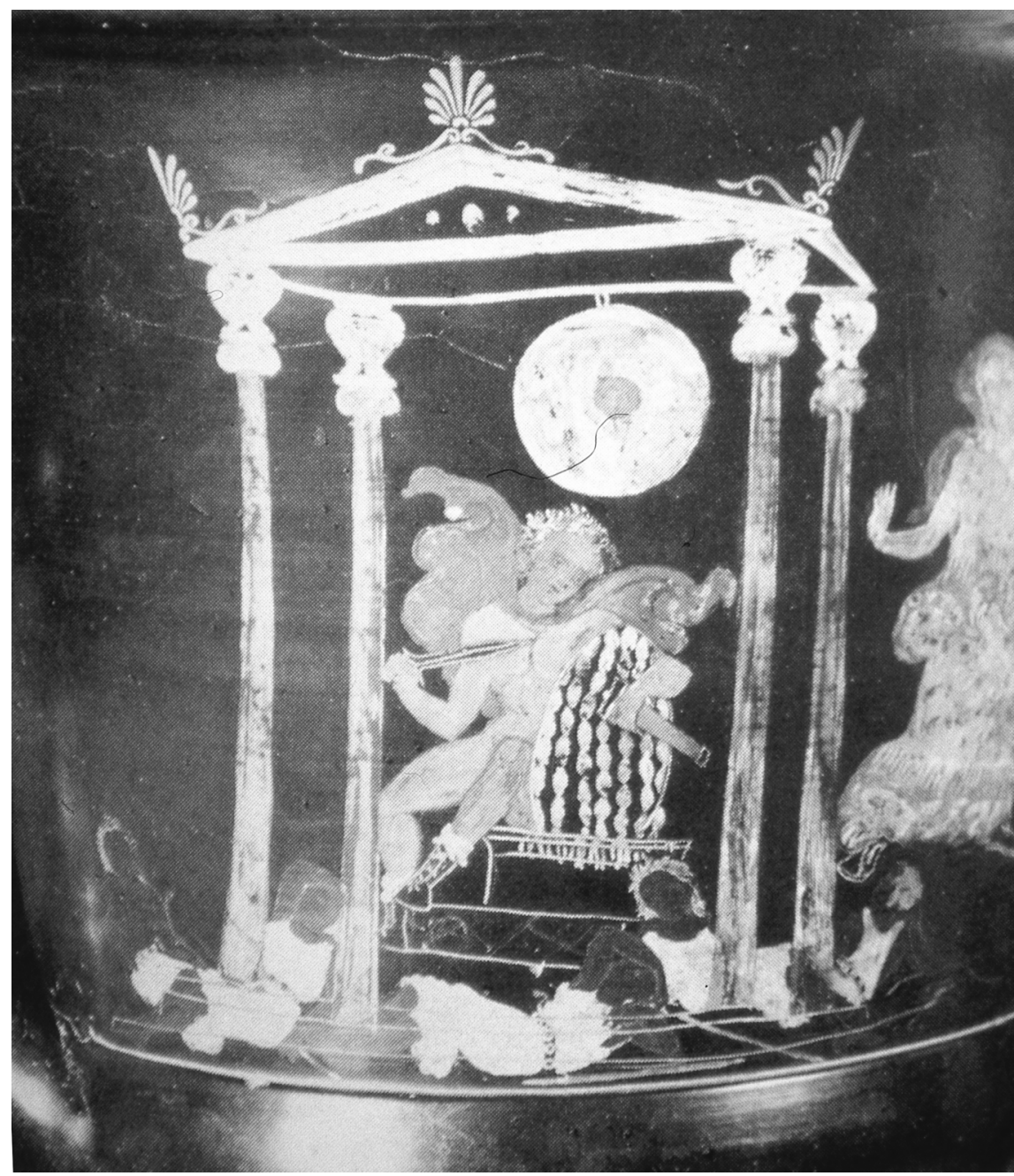

Fig. 1. Cratera de campana apulia atribuida al pintor de Konnakis (ca. 360-350 a.C.). Museo Ermitage (San Petersburgo).

Una cratera de volutas apulia (360-350 a.C. aproximadamente) tiene a Orestes en el centro, en la postura habitual agarrado al ónfalos de Delfos, blandiendo una espada. A la izquierda podemos ver a Apolo sentado y a una Erinia con alas y una antorcha encendida; a la derecha probablemente dos sacerdotisas que huyen asustadas de la Erinia.

Una hidria de Campania (350-325 a.C.) tiene a Orestes, Atenea y Apolo; a la izquierda una Erinia de pie con un quitón largo, grandes alas, serpiente enroscada alrededor de su cuerpo. Lleva una antorcha encendida en la mano derecha y serpientes en la mano izquierda. 


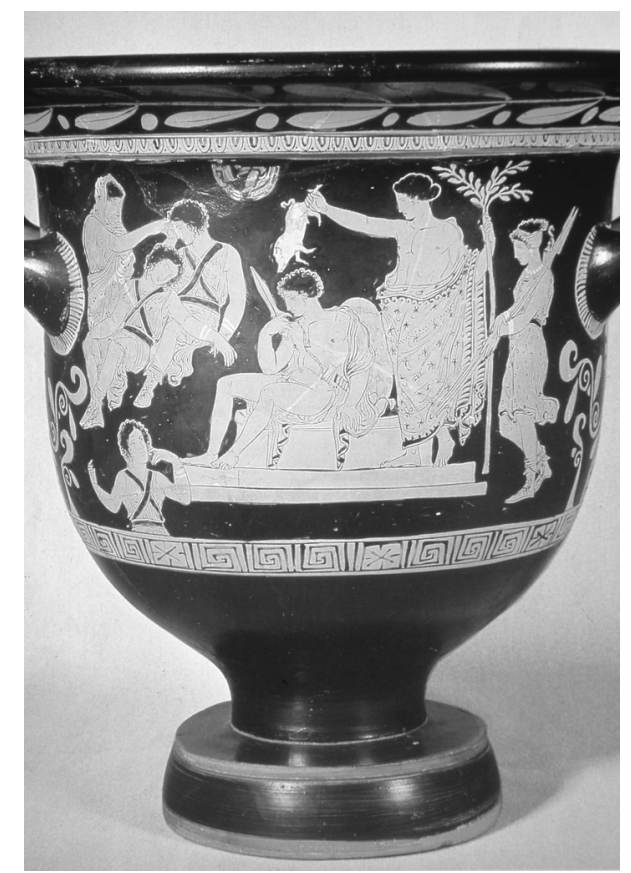

Fig. 2. Cratera de campana apulia del pintor de las Euménides (390-380 a.C.). Museo del Louvre.

Una curiosa escena sobre el mismo tema pero con ciertas variaciones sobre el esquema iconográfico de los vasos anteriores es la de una cratera de campana suritálica (360-350 a.C.). En ella Orestes aparece junto al trípode de Delfos, Apolo está en actitud de disparar su arco, al lado, Pílades, y a la izquierda está representada una Erinia completamente desnuda, su cuello adornado con un collar, y con grandes alas desplegadas. Es la única imagen de una Erinia desnuda, desprovista de sus atributos más corrientes (antorchas, serpientes) y en cambio coquetamente adornada. No es común tampoco representar figuras femeninas desnudas en la cerámica de figuras rojas a no ser en contextos eróticos o de debilidad femenina (en casos de rapto o violación). Y es más peculiar aquí, en una imagen en conexión con la tragedia Euménides, en la que ningún personaje era representado desnudo en escena.

El hecho de que estas imágenes estén claramente situadas en Delfos -el ónfalos figura normalmente en el centro de la composición y a él se abraza Orestespero en ellas aparecen a la vez Apolo y Atenea, muestra que no están ilustrando una escena en particular de la tragedia, sino que son una combinación de varias escenas a la vez, que pueden tener dos o más lecturas.

Por otro lado, son especialmente interesantes dos imágenes que representan la escena al comienzo de Euménides cuando el fantasma de Clitemestra se aparece al coro de Erinias dormidas y las incita a despertar y no dejar su tarea de perseguir a Orestes. 


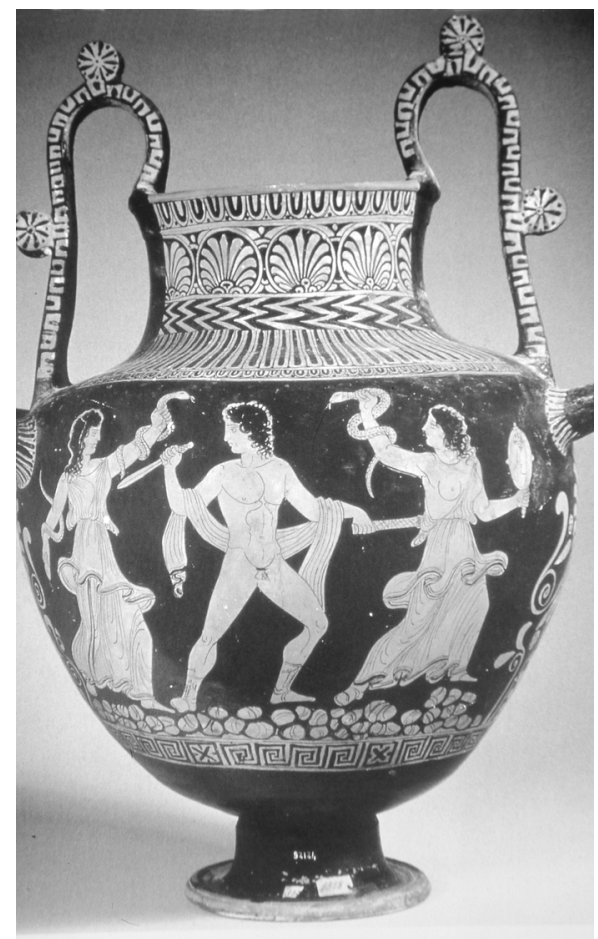

Fig. 3. Nestóride lucania atribuida al pintor de Brooklyn-Budapest (380-360 a.C.) Museo Nacional de Nápoles.

Así, una cratera de campana apulia de figuras rojas del 390-380 a.C. tiene a Orestes sentado sobre el altar, Apolo sujetando un cerdo encima de su cabeza mostrando el sacrificio ritual de purificación de Orestes y Ártemis. A la izquierda, el fantasma de Clitemestra se dispone a despertar a dos Erinias dormidas; por debajo, una tercera Erinia — visible sólo la mitad de su cuerpo- acaba de despertarse. Tienen túnicas, cinturón y serpientes en el cabello. Aunque esta escena no parece tener un carácter teatral en el sentido de que sea una copia directa de una representación dramática, sin duda está inspirada por ella.

Una nestóride lucana de figuras rojas (380-360 a.C.) presenta a Orestes en el centro, de pie, desnudo, en el acto de desenvainar su espada. A cada lado de él hay una Erinia, representadas con túnicas, sin alas y con una serpiente enroscada en cada brazo. La Erinia de la derecha lleva un espejo en la mano en el que se ve la cara de perfil de una mujer con corona que ha sido interpretada como la cara de Clitemestra. Sería esta escena otra interpretación de la aparición del fantasma de Clitemestra en Euménides aunque es el único caso en la cerámica griega en que se representa un eidolon o fantasma de un muerto en un espejo. Es además la única ocasión en que el espejo aparece como un atributo de las Erinias. Sin duda para los griegos el espejo tenía un carácter mágico y el artista aquí ha querido re- 
presentar cómo las Erinias podían poseer la capacidad de conjurar esa imagen fantasmal desde el mundo de los muertos. Está inspirada por la tragedia de Esquilo pero no trata de ser una imagen de ésta propiamente dicha, sino una particular visión del pintor del vaso de la aparición de Clitemestra incitando a las Erinias en su venganza contra Orestes ${ }^{20}$.

Otras imágenes ilustran probablemente la escena de la tragedia que se desarrolla en el Areópago ${ }^{21}$, como por ejemplo una cratera de columnas ática (440-430 a.C.) en la que encontramos otro esquema que se corresponde con la escena en Atenas, aunque la composición es bastante similar. Orestes, arrodillado sobre un suelo rocoso que sugiere la colina del Areópago, se enfrenta con su espada a una Erinia alada, con túnica corta y con serpientes entrelazadas en sus brazos. Tras Orestes, Apolo y una figura femenina con antorchas que podría ser una sacerdotisa.

Otra cratera de columnas ática (440-430 a.C. aproximadamente) tiene a Orestes en la misma postura que la imagen anterior. Delante de él Apolo parece enfrentarse a una Erinia alada, con serpientes en los brazos y quitón corto adornado. Al otro lado de Orestes se encuentra Atenea.

No hay escenas que representen la votación ante el Areópago con Atenea dominando la escena, ni la procesión final con la que termina la tragedia, cuando las Erinias serán admitidas como divinidades benefactoras de la ciudad de Atenas.

Por otro lado, es interesante ver a las Erinias cuando son representadas en el Hades, con otros personajes, asistiendo a los castigos de algunos de los torturados, como Ixión, Teseo o Pirítoo. Son vasos suritálicos con escenas en el mundo infernal presididas por Hades y Perséfone. Estas escenas no tienen nada que ver con una obra dramática, pero en ellas podemos ver cómo la iconografía de las Erinias se mantiene con similares características aunque en un contexto diferente. El hecho de que estas representaciones surjan en la misma época que las que se refieren a la escena con Orestes - las más populares, por la influencia de la tragedia de Esquilo- sugiere el interés por presentarlas como criaturas infernales.

Por ejemplo, una cratera de volutas apulia (350 a.C. aproximadamente) muestra a Hades, Perséfone y Pirítoo. Una Erinia está castigando a Teseo. Tiene alas, un quitón corto y botines.

Otra cratera de volutas del museo de Nápoles (360-350 a.C.) presenta una escena parecida, con Hades, Perséfone, Apolo, Teseo y Pirítoo. En este caso una Erinia con alas, serpientes en su cabeza y antorcha amenaza a Heracles y Cerbero. Se mezclan aquí por tanto varios episodios míticos que tienen lugar en el Hades.

Un ánfora suritálica (330-320 a.C.) ofrece una escena más interesante, que insiste en el papel de las Erinias como encargadas de los castigos infernales. En

20 Un estudio más detallado sobre esta imagen en M. Aguirre, «Fantasmas trágicos: algunas observaciones sobre su papel, aparición en escena e iconografía», Cuadernos de Filología Clásica (G) 16 (2006), 113-114.

21 Cf. Knoepfler, o.c.,79-83. 
este caso podemos ver a dos Erinias, una a cada lado, girando la rueda del suplicio de Ixión. Tienen alas y llevan túnica larga. Otra Erinia surge de abajo, con alas y brazos abiertos, llevando una antorcha en la mano.

El tema de Orestes penetra en el mundo etrusco y romano por influencia de las imágenes griegas, pero las representaciones se centran más en la muerte de Agamenón y Clitemestra y en la historia de Ifigenia y son más escasas las de la purificación de Orestes. Ésta aparece en algunos sarcófagos romanos con la escena de Orestes en Delfos y las Erinias dormidas, por ejemplo, un sarcófago romano de mármol del s. II d.C. que se encuentra en el Museo del Louvre en el que aparece Orestes agachado con dos Erinias una a cada lado y otros personajes. Hay dos figuras que aparecen por detrás de un cortinaje que podrían ser interpretadas como las sombras de Clitemestra y Egisto o simplemente como sus efigies que recuerdan lo que ha ocurrido ${ }^{22}$. En el Museo Arqueológico Nacional de Madrid se conserva un sarcófago romano procedente de Husillos (Palencia) de la misma época (siglo II d.C.) en el que se desarrolla el ciclo de Orestes: en el centro Orestes y Pílades dan muerte a Clitemestra y Egisto. A la derecha, las Erinias, escondidas tras unas cortinas, parecen horrorizadas ante el parricidio. Una de ellas acerca una serpiente al rostro de Orestes que retrocede impresionado. En la escena de la izquierda Orestes y las Erinias descansan fatigados tras la persecución. A la derecha y en los laterales se representa el juicio en el Areópago.

Es posible que en el arte posterior el tema de Orestes y las Erinias se haya configurado también a partir del teatro, es decir que la influencia de la obra de Esquilo - y sus posteriores recreaciones dramáticas - haya sido de esencial importancia para las representaciones artísticas. Y aunque la historia de Orestes $-\mathrm{y}$ asimismo la de Electra- dará lugar a lo largo de los siglos a numerosas tragedias, óperas y obras literarias inspiradas en ella, en la pintura no es apenas conocida hasta el siglo XVIII. En realidad, los temas de la tragedia griega, a diferencia de otros temas mitológicos, no comienzan a ser bien conocidos y tratados en el arte hasta finales del siglo XVII y ya a partir del XVIII, cuando el drama griego fue redescubierto y comienzan a llevarse a cabo traducciones y representaciones de las obras de Esquilo, Sófocles y Eurípides.

Las Erinias o Furias aparecen aisladas, algunas veces relacionadas con la Divina Comedia de Dante o en otros contextos mitológicos diferentes al de la historia de Orestes, por ejemplo, en la ilustración de Botticcelli para El Infierno de la Divina Comedia o, ya en el siglo xIX, en la de Flaxmann para la misma obra ${ }^{23}$.

En la obra de Gustav Klimt «Jurisprudencia» (1903-7), que fue destruída en 1945 pero de la que conservamos en una copia ${ }^{24}$, podemos ver tres mujeres des-

22 Cf. Knoepfler, o.c., 95.

23 Cf. J.D.Reid, The Oxford Guide to Classical Mythology in the Arts 1300-1990s 1, Nueva York y Oxford (1993), 442-443.

${ }_{24}$ Esta obra estuvo expuesta en Madrid en la exposición «La destrucción creadora. Gustav Klimt, el friso de Beethoven y la lucha por la libertad del arte» del 6 de octubre de 2006 al 14 de enero de 2007. El conjunto de obras expuestas entre las que se cuenta ésta fueron pintadas para el techo del Paraninfo central de la Universidad de Viena y fueron rechazadas por su excesiva violencia que no encajaba dentro del 
nudas interpretadas como tres Erinias o Furias aunque algunos críticos opinan que se trata de las Parcas. Sin embargo las serpientes de sus cabellos parecen apuntar más a la iconografía de las Erinias que a la de las Parcas. En su otra obra «El friso de Beethoven" hay otras tres mujeres similares, en este caso consideradas tres Gorgonas, que aparecen junto al monstruo Tifoeo en forma de simio gigante. Evidentemente para Klimt tanto las Erinias como las Gorgonas se caracterizan por ser figuras femeninas que, aparte de las serpientes entrelazadas en sus cabellos, nada tienen de espantoso en el resto de su apariencia física.

Pero ya centrándonos en el tema que nos ocupa, el de las Erinias con Orestes -es decir, de nuevo el tema de la tragedia Euménides-, en ocasiones vamos a encontrar la escena de Orestes perseguido por las Erinias como ilustración a una traducción de la tragedia de Esquilo, como la de John Flaxmann «El fantasma de Clitemestra despertando a las Furias» (1793-4). En su composición de la escena el fantasma de Clitemestra se encuentra en el centro, como un elemento casi arquitectónico, rodeado por esas Erinias dormidas, tal y como aparecen en la obra de Esquilo25.

De esta misma época — siglo XVIII- en adelante algunos pintores han utilizado este tema como motivo de sus cuadros. $Y$ son los artistas que se encuadran dentro del simbolismo los que recrean de forma especial el tema por el valor moral que representa.

Así podemos citar a John Dowmann y su obra «El fantasma de Clitemestra despertando a las Furias» (1781). Este cuadro está claramente inspirado en la tragedia Euménides que fue publicada traducida al inglés en 1777. El tema es el mismo que hemos visto en la imagen anterior. Es el momento de la tragedia en que el fantasma de Clitemestra despierta a las Erinias dormidas. Aquí la iconografía sigue el modelo griego: las antorchas, las serpientes en los cabellos, etc. y está claro el carácter teatral de la escena, por el número de Erinias, que no son tres y sugieren un coro y por las máscaras. Sin embargo, Clitemestra está representada tal y como nos imaginaríamos hoy un fantasma, es decir, una especie de figura luminosa, transparente y blanca. Las Erinias tienen un aspecto espantoso, pero a la vez se las ve aterrorizadas por la visión. En cierto modo son un poco caricaturescas y a juicio de algunos reflejarían la representación privada de una mascarada basada en este tema, como las que eran frecuentes entre las clases altas de la época ${ }^{26}$.

El cuadro de Adolphe William Bouguereau "Orestes perseguido por las Furias» $(1862)^{27}$ presenta otro momento de la tragedia de Esquilo, anterior. En este caso el pintor ha plasmado una escena terrible, con tres Erinias acosando a Orestes, una

arte oficial. Se trataba de una alegoría de la Justicia asociada a la facultad de Derecho y Klimt elige el tema de las Erinias - es decir el tema de la venganza-, en lugar de la diosa Temis o la alegoría tradicional de la Justicia con la balanza.

${ }^{25}$ Para S. Symmons (Flaxmann and Europe Nueva York (1984), 54) el artista seguramente se inspiró en el cuadro de Romney «El fantasma de Darío», que a su vez se inspira en otra escena de aparición fantasmal en la tragedia griega, en este caso de Los Persas de Esquilo.

${ }^{26}$ Sobre este cuadro cf. M. Myrone, Gothic Nightmares. Fuseli, Blake and the Romantic Imagination, Londres (2006), 134.

27 Cf. Reid, o.c., 766. 


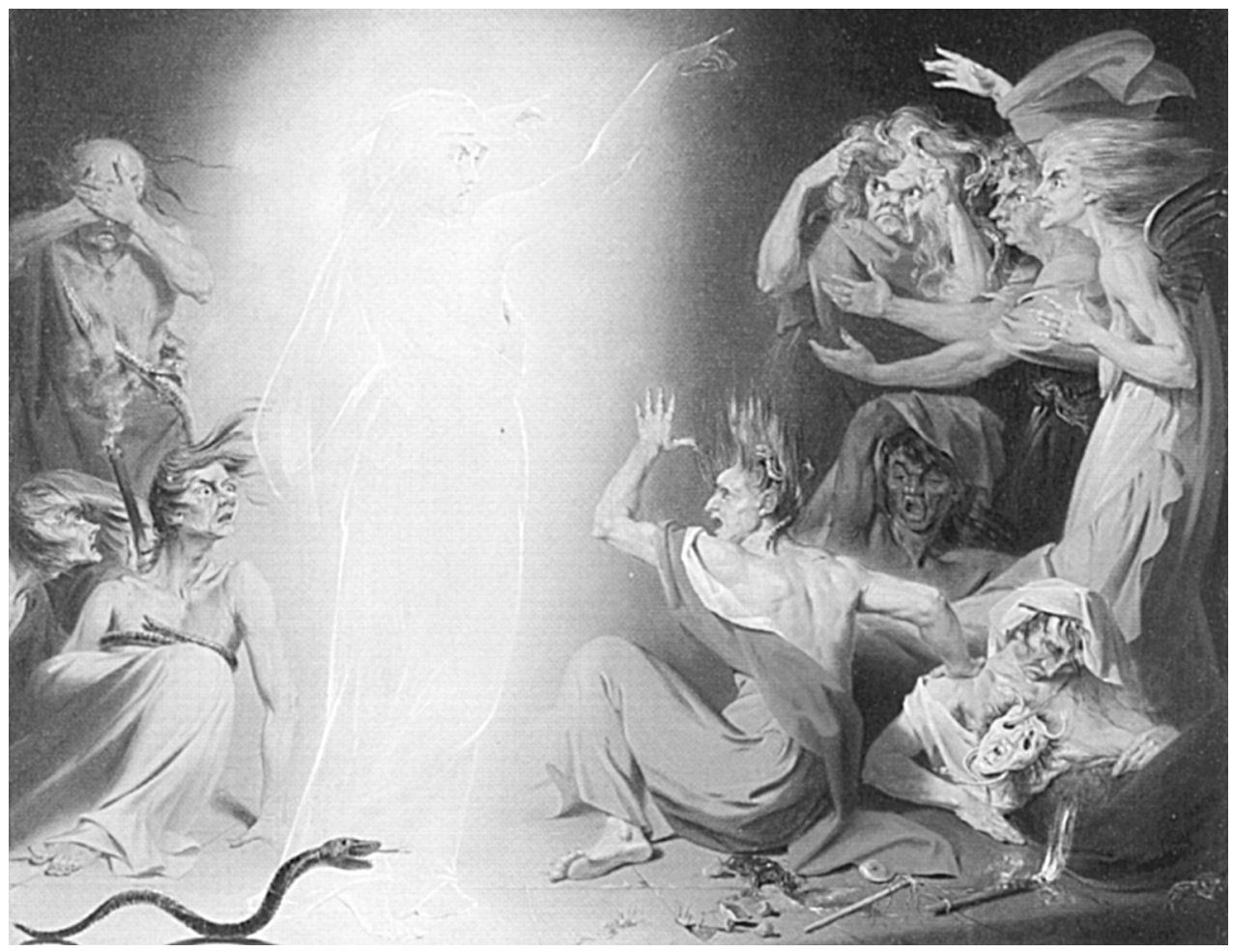

Fig. 4. John Dowmann «El fantasma de Clitemestra despertando a las Furias» (1781). Yale Center for British Art (New Haven).

de ellas sosteniendo en sus brazos el cuerpo de Clitemestra muerta. Orestes se tapa los oídos y elude la visión. Las Erinias están representadas según el modelo griego, con serpientes entre sus cabellos, una con una antorcha encendida, aunque, a diferencia de las imágenes griegas de esta escena, no hay templo de Delfos, ni Apolo o Atenea representados. El pintor claramente alude al momento en que Orestes sufre la persecución que le enloquece, tras haber matado a su madre, hecho que se recuerda de manera dramática en el cuadro con esa imagen de Clitemestra aún con el cuchillo clavado en su pecho todavía sangrando. Está inspirado en la tragedia de Esquilo y en la historia de Orestes, pero no es una imagen teatral sino más bien filosófica ya que el propio Bouguereau escribió sobre el cuadro que había querido plasmar en él la idea del criminal atormentado por los remordimientos.

Carl Rahl pintó en 1865 su cuadro «Orestes perseguido por las Furias», una escena similar a la anterior. Orestes está desnudo en el centro, atromentado por las Erinias que le rodean. Con gestos amenazadores tratan de alcanzarle mientras él se cubre la cabeza con los brazos. Dos llevan antorchas encendidas, y la tercera, la de la izquierda, levanta un puñal. Los colores del cuadro le dan un aspecto tenebroso, 


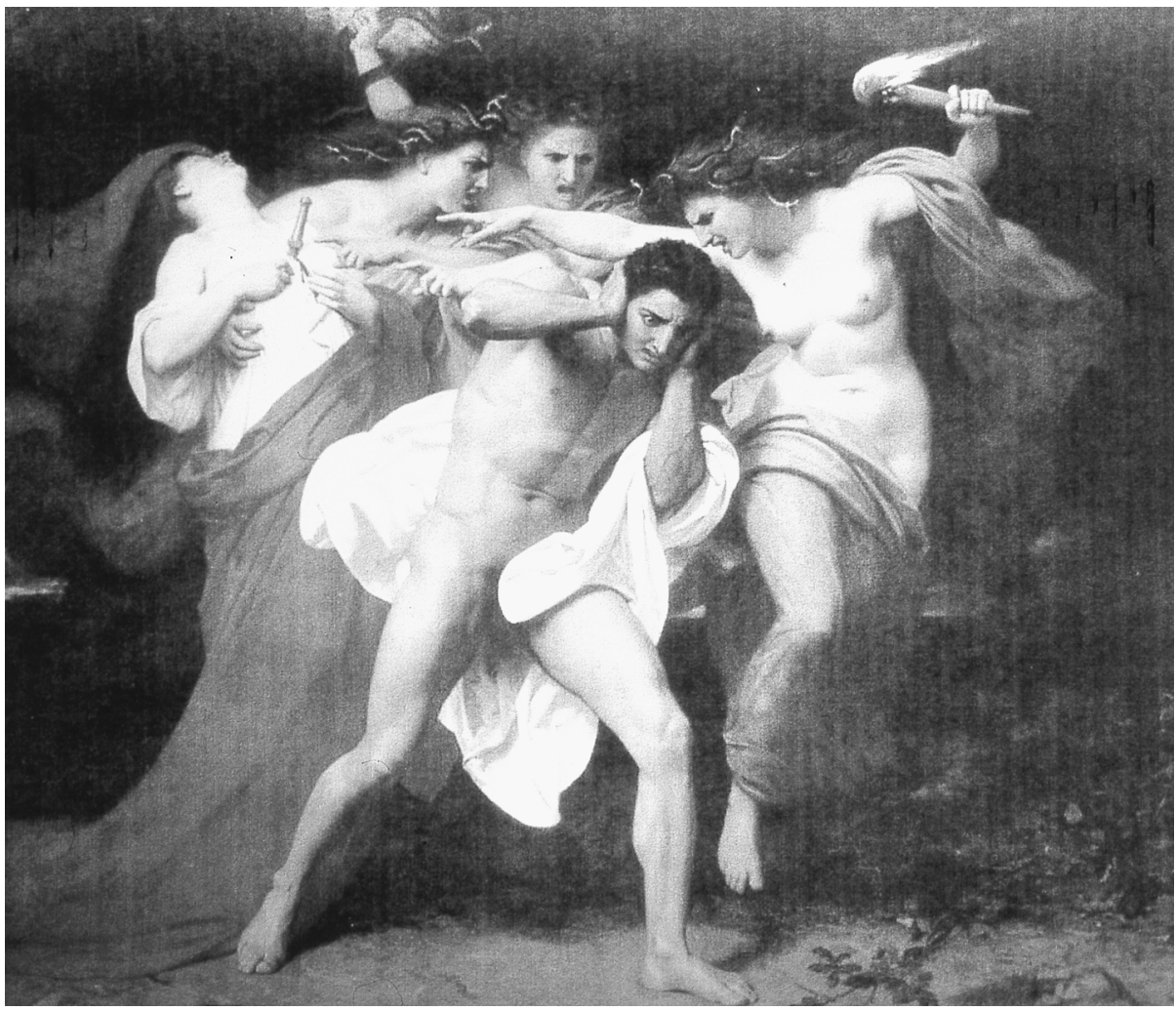

Fig. 5. Adolphe William Bouguereau "Orestes perseguido por las Furias» (1862).

Chrysler Museum of Art (Norfolk, Virginia).

con un fondo oscuro en el que destaca el fuego de las antorchas. En la Erinia de la derecha se pueden ver las serpientes que se enroscan en su cabello.

Gustave Moreau pintó en 1891 el cuadro «Orestes y las Furias», con la escena de Orestes en el templo con tres Erinias aproximándose a él por detrás. Estas Erinias no parecen demasiado espantosas, son tres jóvenes con túnicas y una especie de halo alrededor de sus cabezas, lo que les da — sobre todo a la de frente - un aspecto de santa cristiana a pesar de las serpientes que se enroscan en sus pies. La figura de Orestes desnudo en el suelo con su espada en la mano, recuerda las imágenes griegas, pero el ambiente es totalmente diferente. Se pueden ver aquí algunos de los elementos típicos del arte simbolista de Moreau, así como esas columnas y esas decoraciones orientales que encontramos en otros cuadros suyos.

El pintor simbolista alemán Franz von Stuck pintó un cuadro sobre este tema que presenta a Orestes corriendo perseguido por unas Erinias desnudas con serpientes en sus cabellos. La de delante, que tiene el cuerpo en blanco, lleva serpientes cogidas con sus manos. 


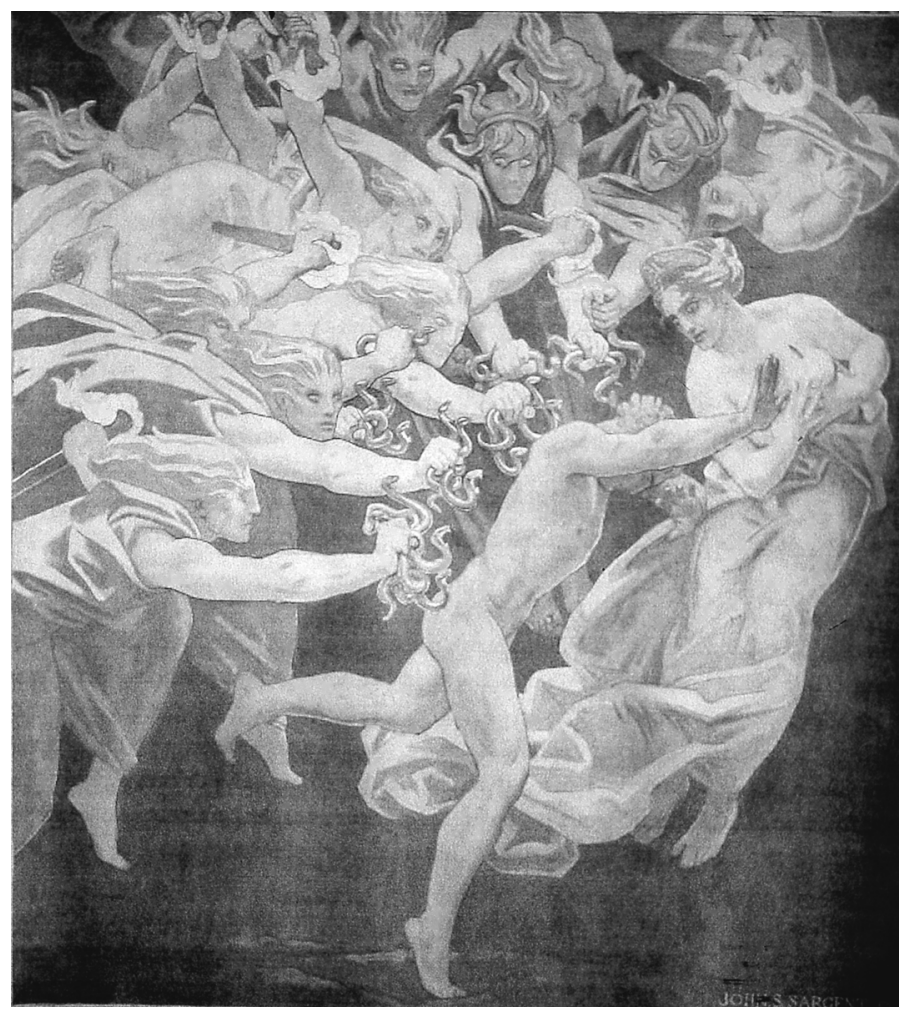

Fig. 6. John Singer Sargent «Orestes perseguido por las Furias» (1921). Museo de Bellas Artes de Boston.

El cuadro del pintor americano John Singer Sargent «Orestes perseguido por las Furias» (1921) —que forma parte de la decoración mural que hizo este pintor para el Museo de Bellas Artes de Boston- nos ofrece una interesante versión del tema: Orestes desnudo trata de huir de toda una banda - ¿quizá un coro?- de Erinias amanazadoras con serpientes en las manos y antorchas. Hay una figura femenina a la derecha de Orestes que podría ser Clitmestra. El fondo rojo del cuadro resalta el horror de la escena.

Con un carácter también teatral pero sobre un tema diferente -en este caso un tema posterior a Euménides: el viaje de Orestes al país de los Tauros que recoge Eurípides en Ifigenia entre los Tauros- tenemos el cuadro de J. H.W. Tischbein «Ifigenia reconoce a Orestes» que probablemente se inspiró en la obra de su amigo Goethe Iphigenia auf Tauris (llevada a escena en 1779) en la que el propio Goethe hizo el papel de Orestes. En este cuadro aparecen las tres Erinias -con su iconografía más común, es decir, serpientes en la cabeza y llevando antorchas-, asomándose a una puerta mientras Ifigenia abraza a su hermano Orestes para calmarlo. Esta escena es una versión diferente de la historia que nos transmite la tragedia de Esquilo y que - como he dicho- es la versión de Eurípides en 
la que Orestes ha huído al país de los Tauros tras matar a Clitemestra perseguido por las Erinias y allí encuentra a su hermana Ifigenia quien le creía muerto. Y esta es la obra en la que Goethe se inspira. En el arte griego en cambio no aparecen Erinias representadas en el contexto de Orestes en el país de los Tauros, sí en el arte etrusco y romano.

También relacionado con la Ifigenia en Táuride de Goethe está el grabado de Kaulbach en el que el artista representa a Orestes levantando las manos como para protegerse de esa horrible visión de las Erinias espantosas que se asoman por detrás de Ifigenia. Los gestos de sus rostros, las serpientes y la antorcha responden a la iconografía típica que hemos ido viendo.

En todos estos cuadros las Erinias están representadas sin alas, siguiendo la tradición del texto de Esquilo y no de esas otras imágenes griegas de los vasos de cerámica que las representan aladas. Frente a ellas, las Gorgonas aparecen con alas desde sus primeras imágenes, ya en el siglo vı a.C. ${ }^{28}$, y asimismo en la recreación que hacen de ellas algunos pintores, como por ejemplo Sir Edward BurneJones en su cuadro «La muerte de Medusa» (1875-78).

En resumen, podemos ver en este estudio un ejemplo de la relación entre iconografía, iconología y teatro. Aunque muchas pinturas de vasos griegos pueden ser asociadas a ciertas tragedias, es sin duda difícil discernir en una escena mitológica si nos encontramos ante la imagen de una representación teatral o no, aunque reconozcamos claramente la escena ${ }^{29}$. Ciertos elementos hacen suponer a veces un carácter teatral de la escena en cuestión pero resulta problemático relacionar con total exactitud y certeza la imagen con un texto o una representación dramática; en cualquier caso, aquí como en otros ejemplos la inspiración del teatro para la utilización y repetición de ciertos temas parece bastante clara. Y en este tema en concreto, la relación entre la obra dramática y la artística —-dada la popularidad del tema de la Orestía — parece haber ido más allá del mundo griego.

${ }^{28}$ Cf. M. Aguirre, «Monstruos y mitos: Las Gorgonas en el mediterráneo», Revista de Arqueología 207 (1998), 22-31.

29 Cf. nota 15. 